\title{
OPEN New glacier evidence for ice-free summits during the life of the Tyrolean Iceman
}

\begin{abstract}
Pascal Bohleber ${ }^{1,2 \varpi}$, Margit Schwikowski ${ }^{3,4,5}$, Martin Stocker-Waldhuber ${ }^{1}$, Ling Fang ${ }^{3,5}$ \& Andrea Fischer ${ }^{1}$

Detailed knowledge of Holocene climate and glaciers dynamics is essential for sustainable development in warming mountain regions. Yet information about Holocene glacier coverage in the Alps before the Little Ice Age stems mostly from studying advances of glacier tongues at lower elevations. Here we present a new approach to reconstructing past glacier low stands and icefree conditions by assessing and dating the oldest ice preserved at high elevations. A previously unexplored ice dome at Weißseespitze summit (3500 m), near where the "Tyrolean Iceman" was found, offers almost ideal conditions for preserving the original ice formed at the site. The glaciological settings and state-of-the-art micro-radiocarbon age constraints indicate that the summit has been glaciated for about 5900 years. In combination with known maximum ages of other high Alpine glaciers, we present evidence for an elevation gradient of neoglaciation onset. It reveals that in the Alps only the highest elevation sites remained ice-covered throughout the Holocene. Just before the life of the Iceman, high Alpine summits were emerging from nearly ice-free conditions, during the start of a Mid-Holocene neoglaciation. We demonstrate that, under specific circumstances, the old ice at the base of high Alpine glaciers is a sensitive archive of glacier change. However, under current melt rates the archive at Weißseespitze and at similar locations will be lost within the next two decades.
\end{abstract}

The majority of the glacier ice volume in the Alps may disappear within the next two centuries ${ }^{1}$. A major scientific question is whether this process of deglaciation is unprecedented within the Holocene. If we want to assess the pace of future deglaciation in the Alps, it is essential to understand past glacier dynamics and their relation to changes in climate ${ }^{2}$. We already have comprehensive information about the maximum extent of Alpine glaciers from the investigation of moraine positions and ages ${ }^{3,4}$. Yet comparatively little is known so far about the times of minimum ice cover or ice-free conditions at high-elevation. Indeed, only the dating of wood fossil emerged from ice melt has made it possible to constrain glacier retreat, but at lower elevation ${ }^{5,6}$. Complementary information to findings from glacier tongues can come from glaciers at high elevations ${ }^{7}$, where the ice is frozen to bedrock. Despite the strong retreat since the Little Ice Age (LIA), access to the oldest ice near bedrock is still complicated for high-elevation areas and usually requires drilling glacier ice cores.

Most previous ice core research in the Alps was aimed at continuous stratigraphic climate records. This limited it to glaciers where there is usually no melting on the surface throughout the year. Few suitable drilling sites exist as they are mostly confined to above $4000 \mathrm{~m}$ altitude, e.g. locations in the Western Alps ${ }^{8}$. In the Eastern Alps and at elevations below $4000 \mathrm{~m}$, such records are sparse, with only one ice core record obtained from an already partially temperate site at Ortler ${ }^{9}$ and at the temperate Silvretta glacier ${ }^{10}$. Still, it generally holds that if basal ice temperatures are below the melting point, the so-called "cold ice" remains frozen to bedrock. If it moves at all, it does so by slow internal deformation, in contrast to temperate ice (i.e. ice at around $0{ }^{\circ} \mathrm{C}$ ), which is able to slide along the bedrock ${ }^{11}$. Even though its remaining thickness is only around $10 \mathrm{~m}$, millennial-old stagnant cold ice has recently been found at the base of an Alpine summit glacier ${ }^{12}$. Constraining the maximum age of the stagnant ice near bedrock can indicate past ice-free periods, followed by neoglaciation ${ }^{13}$. Hence this age information alone contains important information on paleoclimatic conditions.

Until recently, only human artifact findings were discussed in connection with low stands of high-elevation glaciers in the Alps; at Schnidejoch pass (2750 m, Bernese Alps $\left.{ }^{7}\right)$ and the "Tyrolean Iceman" in the Eastern

${ }^{1}$ Institute for Interdisciplinary Mountain Research, Austrian Academy of Sciences, Innsbruck, Austria. ${ }^{2}$ Department of Environmental Sciences, Informatics and Statistics, Ca'Foscari University of Venice, Venice, Italy. ${ }^{3}$ Paul Scherrer Institute, Villigen, Switzerland. ${ }^{4}$ Department for Chemistry and Biochemistry, University of Bern, Bern, Switzerland. ${ }^{5}$ Oeschger Center for Climate Change Research, University of Bern, Bern, Switzerland. ${ }^{\square}$ email: pascal.bohleber@oeaw.ac.at 
$\mathrm{Alps}^{14}$. Schnidejoch pass is easily blocked by glacier advances, making the artifact findings a sensitive indicator of past glacier minima. Radiocarbon dating of artifacts indicates three phases of minimal ice extent, suitable for crossing the pass. The earliest phase was around 6.8-6.3 ka cal, a second phase from 5.7 to $4.9 \mathrm{ka}$ cal, and an adjacent third period from 4.9 to $4.2 \mathrm{ka} \mathrm{cal}^{15}$. The Tyrolean Iceman mummy emerged from a small ice field, vanished since, at Tisenjoch, a saddle located at $3210 \mathrm{~m}$. Radiocarbon dating of the mummy indicated that the Iceman lived roughly $5.1-5.3 \mathrm{ka} \mathrm{cal}^{14,16}$. The well-preserved state of the corpse and of artifacts suggests that they had been conserved in frozen conditions. The ice field at Tisenjoch must therefore have been present during several known periods of glacier retreat, such as the Roman and Medieval warm phases ${ }^{17}$. Unfortunately, after the discovery of the Iceman, pollen analyses were only conducted on the surrounding ice ${ }^{18}$. With the arrival of modern radiometric ice-dating techniques based on ${ }^{14} \mathrm{C}$-dating of the water-insoluble organic carbon fraction of carbonaceous aerosols embedded in the ice matrix, it is now possible to constrain the age of the glacier ice itself $^{19,20}$. Dating the ice with today's radiometric techniques could have told us if the Iceman had in fact died in a mostly ice-free environment, or if he fell into a crevasse on a glacier-covered Tisenjoch.

\section{Results}

The unique site for old ice preservation at Weißseespitze. The Weißseespitze summit glacier (WSS, $3500 \mathrm{~m}$ ) marks the highest point of Gepatschferner in the Austrian Alps. It is a unique site: (1) located only $12 \mathrm{~km}$ from the Iceman location, it offers a potential surrogate to investigate the local glacier conditions during the lifetime of the Iceman; (2) it has a dome-shaped glacier geometry, which is an extremely rare feature in the Alps (Fig. 1). Historical photographs dating back to about 1888, maps and digital elevation models, as well as direct measurements at the summit ice dome reveal continuous volume loss since the LIA maximum (Table 1) around 1855 for Gepatschferner ${ }^{21}$. The limited ice thickness and dome geometry mean minimal to no ice flow, confirmed by differential GPS measurements at stakes in 2018 and 2019. In these circumstances, the influence of ice dynamics at the ice divide is negligible for ice age interpretation. Despite the ablation measured at stakes in 2018 and 2019, englacial borehole temperatures remained permanently sub-zero at $1 \mathrm{~m}$ below surface, with $-3{ }^{\circ} \mathrm{C}$ at $9 \mathrm{~m}$ depth, implying that the ice is frozen to bedrock ("Methods" section).

Ice core analysis and glacier age constraints. In March 2019, two parallel cores were drilled $11 \mathrm{~m}$ to bedrock at the ice divide with nearly flat bed conditions. Visible layers of refrozen meltwater indicate that there was only limited occasional melt at this site when this ice was formed. The main part of the ice core includes bubble-rich glacier ice, the likely result of dry metamorphosis of snow. This view is supported by stable oxygen $\left(\delta^{18} \mathrm{O}\right)$ and hydrogen $(\delta \mathrm{D})$ ratios of a range typical for the seasonal variation in snow at this altitude, with no deviation from the meteoric water line ("Methods" section). Within the upper $4 \mathrm{~m}$ of ice, a tritium content in the order of $100 \mathrm{mBq} / \mathrm{kg}$ suggests that the ice was formed before widespread tritium release from nuclear weapons tests in the early 1960s (maximum concentrations in 1963 are expected to exceed $10 \mathrm{~Bq} / \mathrm{kg}$ ) and that the layers from that time had already been removed by melting. The present surface at WSS is thus older than 1963, with the remaining ice the remnant of an originally thicker ice cap. The aerosol-based micro- ${ }^{14} \mathrm{C}$ dating of five samples from the ice core returned ages continuously increasing with depth, from $(0.62 \pm 0.35) \mathrm{ka}$ cal (i.e. calibrated years in ka before 1950, 1 sigma range) at about $4.5 \mathrm{~m}$ depth to $(5.884 \pm 0.739)$ ka cal just above the bed (Fig. 2 and "Methods" section). All ages are reported in the text on this timescale in ka. The original dates are found in the given references.

\section{Discussion}

We evaluated the new evidence from Weißseespitze, first, in view of existing information regarding the regional climate history, followed by the pan-Alpine context of ice-dated glacier minima. For the latter, we paid special attention to co-evaluating maximum age and elevation of all sites.

Despite the drastic mass loss on the surface in today's conditions, the basal ice was found to remain frozen to the bed. Our dating of the ice just above bedrock indicates that the ice body at WSS formed earlier than (5.9 \pm 0.7$)$ $\mathrm{ka} \mathrm{cal}$ and has been glaciated continuously ever since. This implies that even the WSS summit location at $3500 \mathrm{~m}$ altitude was ice-free during an interval prior to $(5.9 \pm 0.7) \mathrm{ka}$. In the context of other regional climate evidence, this finding is consistent with the glacier length reconstructions of Gepatschferner, which document a distinct minimal extent starting around $5.9 \mathrm{ka}^{21}$. Likewise, at around 5.3-5.1 ka cal, no ice existed at nearby Tisenjoch, at $3210 \mathrm{~m}^{22}$. The fact that the lifetime of the Iceman falls within the maximum age range determined for the WSS summit glacier suggests that a rather rapid neoglaciation ended the formerly near ice-free conditions at the summits in this region.

The end of the so-called "Holocene Climatic Optimum"14,23 is also observed in Austrian stalagmite records, indicating the onset of a cooling period around $5.9 \mathrm{ka}^{24}$. In the Eastern Alps, tree-ring-dated subfossil wood remains indicate that several advances occurred between 5.9 and $5.5 \mathrm{ka}$ at three different glaciers in the Alps: Unteraar, Pasterze, Tschierva ${ }^{25}$. The former two have much longer response times than Tschierva, and generally fluctuations of glacier tongues deviate from mass balances at summit glaciers because the terminus position also depends on ice dynamics and because wind erosion affects net accumulation at summits. Nonetheless, the general picture agrees well. Around $5.9 \mathrm{ka}$, there was a limited advance at Tschierva glacier, reaching the 2000 ice extent and ending the preceding warm period ${ }^{25}$. During those warm periods, the tree line was up to $165 \mathrm{~m}$ above the 1980 tree line in Kaunertal, in ultimate vicinity to $\mathrm{WSS}^{26}$. A chironomid record obtained at Schwarzsee in nearby Oetztal suggests that roughly between 5.2 and $4.5 \mathrm{ka}$ cal a climate transition occurred, with a distinct cooling trend in summer temperatures, which prevailed until the end of the LIA ${ }^{27}$.

This is consistent with other regional evidence provided by the Oberfernau bog sediments (Buntes Moor): a radiocarbon-dated layer marks the end of peat growth during a warm phase (Fig. 3). From about 4.2-3.9 ka cal 


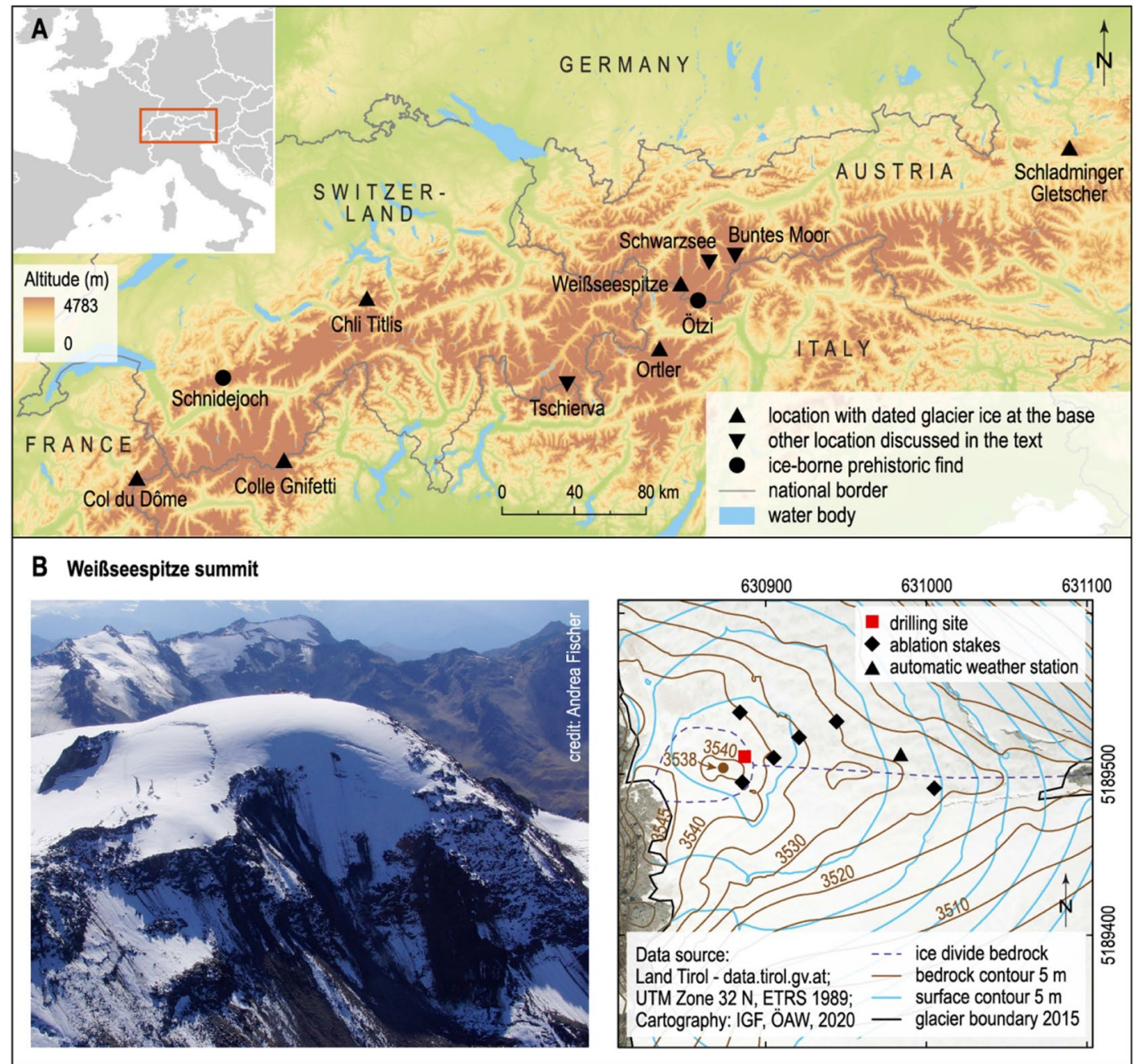

Figure 1. The location of the Weißseespitze summit glacier, the discovery site of the Tyrolean Iceman ("Ötzi”) and other sites discussed in the text (A). Shown in the bottom row is a close up of the glacier topography at Weißseespitze summit and the precise drilling location $(\mathbf{B})$. Note the unique dome shape of the summit glacier. Data sources part A: EuroBoundaryMap, copyright EuroGeographics; CCM River and Catchment Database copyright European Commission-JRC, 2007; CIAT-CSI SRTM (http://srtm.csi.cgiar.org); Cartography: IGF, ÖAW, 2020; under a CC-BY-NC-SA 4.0 International License (https://creativecommons.org/licenses/ by-nc-sa/4.0/). Maps made with licensed software Arc Map 10.6.1 (https://desktop.arcgis.com/en/arcmap/), figure made with licensed software Adobe Illustrator CS6 (https://www.adobe.com).

\begin{tabular}{|c|c|c|c|c|c|}
\hline \multirow[b]{2}{*}{ Period } & Elevation change at drilling site (DoD $[\mathrm{m}])$ & & \multirow[b]{2}{*}{ DEM } & \multirow[b]{2}{*}{ Vert. accuracy $(\mathbf{m})$} & \multirow[b]{2}{*}{ References } \\
\hline & $\Delta \mathrm{H} /$ year & & & & \\
\hline $2018-1969$ & -0.29 & & 1969 & \pm 1.9 & 29 \\
\hline \multirow[t]{3}{*}{ 2018-1997 } & -0.20 & & 1997 & \pm 0.7 & 29 \\
\hline & Ablation at stake $(\mathrm{m})$ & & & & \\
\hline & $\Delta \mathrm{H} /$ year & & & & \\
\hline 2018 & -0.88 & \pm 0.02 & & & This work \\
\hline 2019 & -0.63 & \pm 0.02 & & & This work \\
\hline
\end{tabular}

Table 1. Elevation change as ice loss indicator at Weißseespitze summit, given in metres per year and derived from digital elevation models (DEM, previous studies) and direct measurements by ablation stakes (this work). DoD difference of DEMs. 


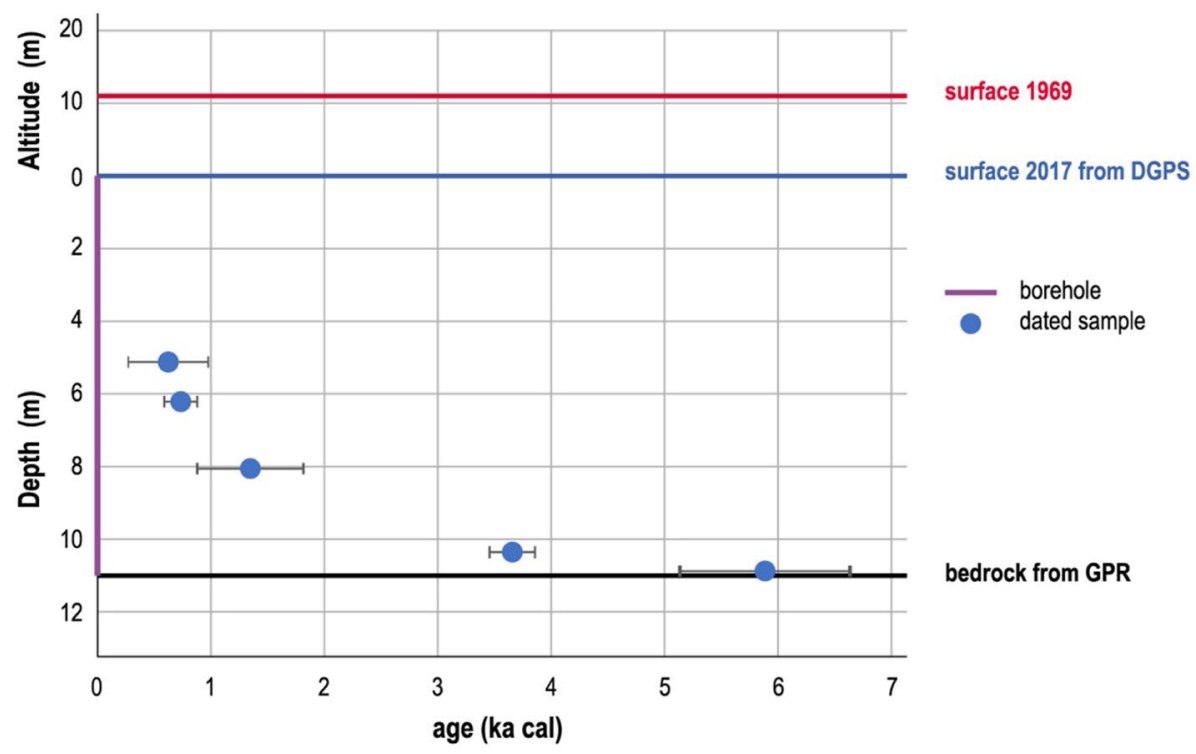

Figure 2. Depth-age relation of the Weißseespitze ice core, obtained by aerosol-based micro-radiocarbon dating of the ice. Also shown is the reconstructed surface elevation loss between 1969 and 2017. Figure made with licensed software Adobe Illustrator CS6 (https://www.adobe.com).

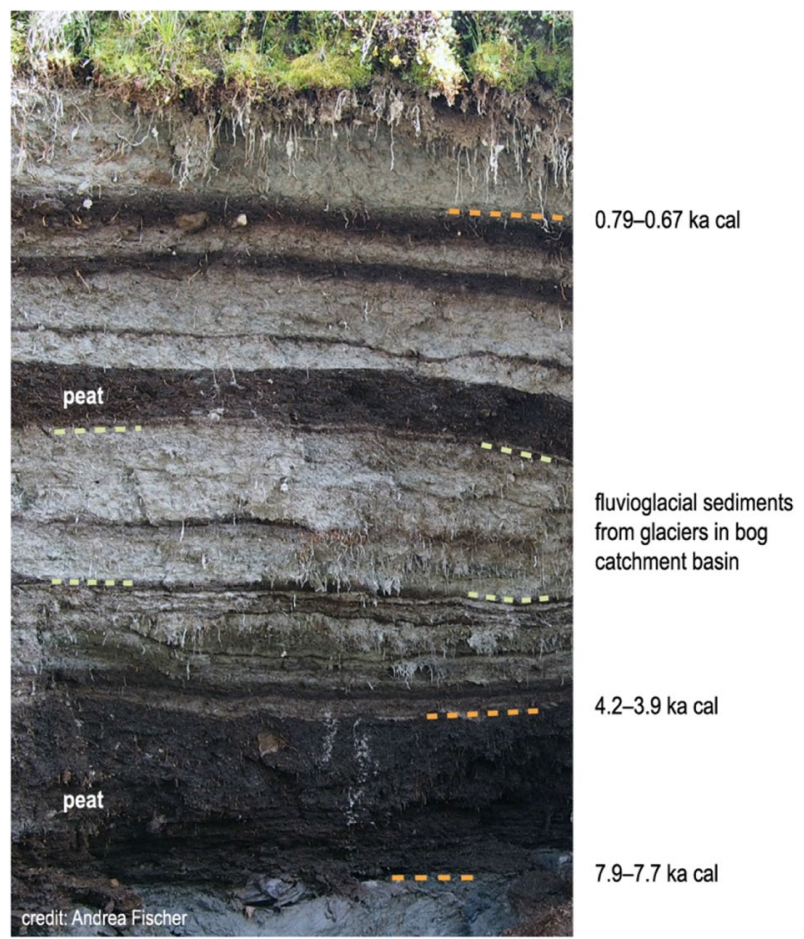

Figure 3. Photograph of the Buntes Moor bog profile with indicated radiocarbon ages ${ }^{28}$ as orange dashed lines. Buntes Moor is located contiguous to the LIA terminus of Fernauferner glacier. Grey layers are fluvioglacial sediments from the basin (e.g. yellow dashed lines). Dark layers are peat formed during warm periods. Figure made with licensed software Adobe Illustrator CS6 (https://www.adobe.com).

onwards, the fluvioglacial sediments indicate the presence of glaciers in the catchment area, i.e. a cooler period ${ }^{28}$. Although the effective altitude of the glaciers leading to the fluvioglacial deposits is not closely defined, it must have been significantly lower than the WSS summit. In this regional context, the findings from WSS fit remarkably well into a general picture of regional warm conditions ending around $5.9 \mathrm{ka}$ at high altitude. This was 


\begin{tabular}{|l|l|l|l|l|}
\hline Site name & Elevation $(\mathbf{m})$ & Maximum age $(\mathbf{k a}$ cal) & Uncertainty $(\mathbf{k a})$ & References \\
\hline Schladminger Gletscher & 2700 & 4.0 & 0.3 & 12 \\
\hline Schnidejoch I & 2756 & $4.9-4.2$ & n.a & n.a \\
\hline Schnidejoch II & 2756 & $5.7-4.9$ & n.a & 15 \\
\hline Schnidejoch III & 2756 & $6.8-6.3$ & 0.1 & 15 \\
\hline Chli Titlis & 3030 & 5.2 & n.a & 12 \\
\hline Iceman Oetzi & 3210 & $5.3-5.1$ & 0.7 & 14,16 \\
\hline Weißseespitze & 3500 & 5.9 & 0.4 & This work \\
\hline Ortler & 3859 & 6.7 & 0.6 & 9 \\
\hline Col du Dome-flank & 4200 & 5.0 & 0.2 & 32 \\
\hline Colle Gnifetti-flank & 4450 & 4.1 & n.a & 20 \\
\hline Colle Gnifetti-saddle & 4450 & $>11.5$ & & 19,31 \\
\hline
\end{tabular}

Table 2. Compilation of glacier maximum age constraints.

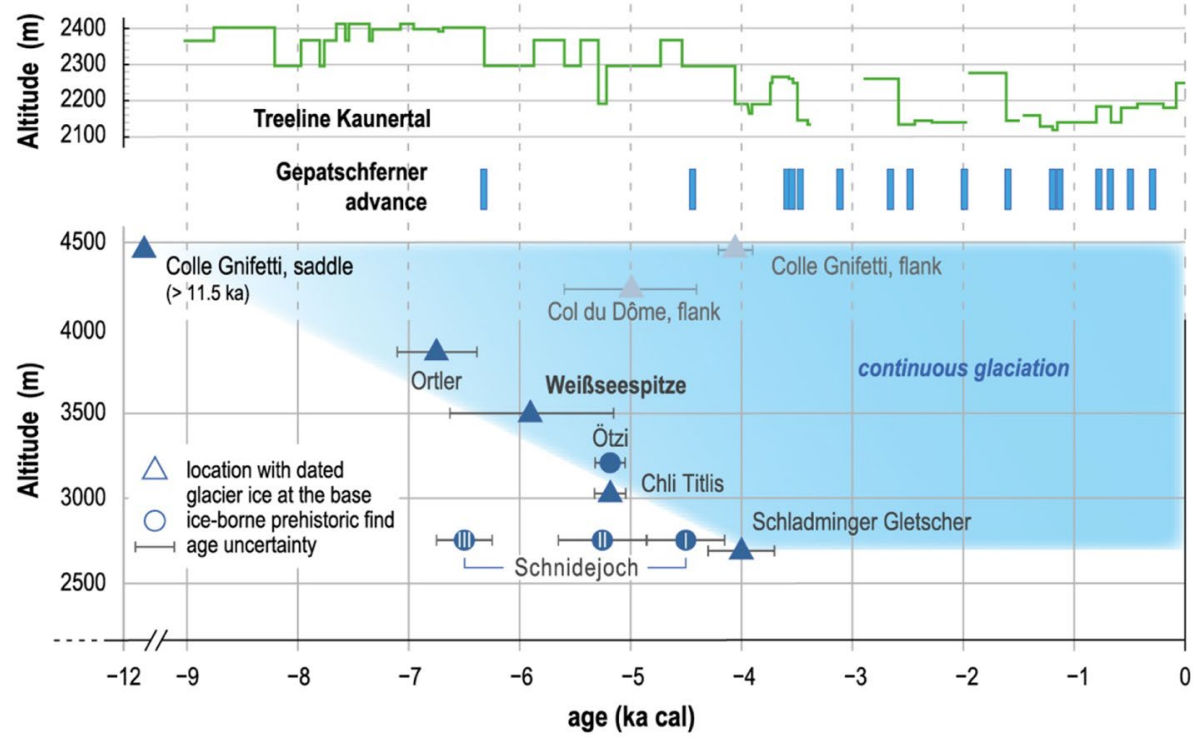

Figure 4. Compilation of dated past neoglaciation events at high-elevation locations in the Alps. Note the general correspondence between glacier maximum age and its altitude. The blue shaded area indicates the period of continuous ice cover. Also shown are the tree line reconstruction from Kaunertal ${ }^{26}$ and the reconstructed advances of Gepatschferner greater than its 1960 extent $^{21}$. References: Colle Gnifetti saddle ${ }^{19,31}$, flank ${ }^{20}$; Col du Dome ${ }^{32}$; Ortler ${ }^{9}$; Iceman "Ötzi”"14,16; Chli Titlis and Schladminger Glacier ${ }^{12}$; Schnidejoch ${ }^{15}$. Figure made with licensed software Adobe Illustrator CS6 (https://www.adobe.com).

followed by a period of glacier advance that started around the lifetime of the Iceman, with a delayed onset of glaciation on lower elevation summits.

The findings from WSS are integrated in an overview of already existing maximum age constraints (Table 2), in order to further investigate the neoglaciation history of high-elevation glaciers throughout the Alps, and the role of the altitude of the site. As shown in Fig. 4, this compilation reveals a remarkable gradient in the onset of neoglaciation in relation to the altitude of the site. Although the altitude of glacier tongues depends primarily on precipitation, as suggested by today's glacier distribution in Austria ${ }^{29}$, this may not be true of high Alpine glaciers. At high-elevation and summit locations, glaciers are typically very limited in size and heavily exposed to wind erosion as a main constraint on net accumulation there ${ }^{8}$. Instead, the dependence on altitude found here suggests a primary connection to mean annual temperature, and its lapse rate, for neoglaciation at these sites. In a simplistic view, a cooling trend would lead to snow accumulation, prolonged positive mass balance and subsequent ice formation on highest elevation sites earlier than on lower elevation, as the ablation rate is smaller at the former. Vice versa, warm periods might lead to increased ablation and prolonged negative mass balance on lower sites, leaving higher glaciers unchanged in geometry, as is the case today for the highest summits of the Western Alps ${ }^{30}$.

Within the region of WSS, maximum glacier age constraints were obtained from a deep ice core drilled at Ortler summit glacier: aerosol-based micro- ${ }^{14} \mathrm{C}$ dating indicates a glacier formation starting earlier at the higher 
altitude of around $3860 \mathrm{~m}$, namely around $(6.7 \pm 0.4) \mathrm{ka} \mathrm{cal}^{9}$. For glaciers above $4000 \mathrm{~m}$, maximum age constraints were obtained from ice cores drilled at Colle Gnifetti (4450 m, Monte Rosa massif) and Col du Dôme (4300 m, Mont Blanc massif). Both glaciers are in the highest region of the glacier's accumulation zone and feature a saddle-shaped geometry. As opposed to the ice dome at WSS, the saddle geometry affects the interpretation of the ice core dating in relation to glacier maximum age constraints. At Colle Gnifetti, for two ice cores drilled close to the saddle point, radiocarbon dates from the deepest layers point to ice older than $11.5 \mathrm{ka} \mathrm{cal}^{19,31}$. In contrast, in an ice core drilled at a flank position, a basal age of only $(4.1 \pm 0.2) \mathrm{ka}$ cal was obtained ${ }^{20}$. Likewise, for an ice core drilled at a flank position at Col du Dôme, the basal age was constrained recently to about $(5.0 \pm 0.6) \mathrm{ka} \mathrm{cal}^{32}$.

Two non-exclusive interpretations may explain the age difference between saddle and flank locations. Due to ice flow at flank positions, the deepest ice layer originating from the neoglaciation may have been severely thinned, making it difficult to adequately resolve its age in a bulk sample. Moreover, the original neoglaciation may have started as a small ice patch around the saddle and not reached the flanks until a further build-up of the glacier was completed. Notably, if taken at face value as the maximum glacier age, the radiocarbon dates from the saddle positions at Colle Gnifetti are a good fit with the elevation gradient of neoglaciation revealed at sites below $4000 \mathrm{~m}$ (Fig. 4).

The elevation-age gradient implies that in the Alps only the highest elevation sites, such as Colle Gnifetti, remained ice-covered throughout the Holocene. This view is corroborated by the fact that the summits above $4000 \mathrm{~m}$ show only minor volume changes even under current climate conditions ${ }^{30}$. Regarding the presence of glaciers below $4000 \mathrm{~m}$, Holocene climate variability has sufficed to induce their de- and subsequent neoglaciation. Considering the current ice loss at WSS and elsewhere, a systematic shift towards a warmer future climate will eradicate these ice archives permanently.

Although the spatial density of dated ice archives is particularly high in the case of the Alps, our approach can, in principle, be transferred to other mountain ranges to study their Holocene neoglaciation history. This appears especially promising where age constraints on the deepest layers of high-elevation glaciers already exist ${ }^{33}$. However, the discussion of the maximum age constraints at Colle Gnifetti illustrates the importance of topographic effects for interpreting the fluctuation and presence of glaciers as indicators of climate ${ }^{34}$ and climate change ${ }^{29}$. In this context, it is worth noting that point mass balance data have been shown to reflect changes in climate better than total mass balance or terminus fluctuation ${ }^{35}$. Cold high-elevation glaciers with low ice dynamics, as almost ideal-typical at WSS, thus present a more direct link to past climate change than terminus fluctuations. In addition, the altitude of the site affects the sensitivity of any glaciers to changes in climate. Although the altitudinal target range may be different for every mountain range, we have demonstrated here for the Alps how certain high-elevation glaciers provide valuable information of Holocene glaciation. This provides important background knowledge for planning sustainable development in mountain regions as they approach nearly icefree conditions in a warmer future climate.

\section{Conclusion}

In a compilation with existing glacier age constraints, the unique ice dome at Weißseespitze has closed a regional and altitudinal gap to reveal the first direct evidence for an elevation gradient of Holocene neoglaciation in the Alps. While only the highest elevation sites remained ice-covered throughout the Holocene, summits around 3000-4000 m were likely ice-free during the Mid-Holocene or covered by glaciers distinctly smaller than today. Around the lifetime of the Tyrolean Iceman and slightly earlier, rapid ice formation started and some of this ice cover exists to this day. Impressive current melt rates threaten the extinction of these ice archives: Weißseespitze glacier, which has accumulated over nearly 6000 years, may disappear within just two decades. However, it may not be the deglaciation of the summits during the Holocene that is unprecedented, but its pace, on which we urgently need extensive empirical information. Our findings demonstrate that the cold ice at certain glaciers, even below $4000 \mathrm{~m}$, is indeed a sensitive archive that delivers a baseline of at least 5 millennia of Alpine glacier change, which allows us not only to tackle past climate variability, but also to find evidence for the effects of climate change mitigation over future decades.

\section{Methods}

Site characteristics. The summit of Weißseespitze features a unique ice dome geometry, with its main ice divide running roughly from an ice-free section in the east towards the cliff on its western side. The ice thickness around the ice divide ranges from 6 to $12 \mathrm{~m}$ measured with a GSSI SIR $4000 \mathrm{GPR}$ ( $500 \mathrm{MHz}$ ). The total surface elevation change since 1969 exceeds $10 \mathrm{~m}$, based on digital elevation models (Table 1). No presence of a firn layer was found in snow pits apart from seasonal snow coverage. Englacial temperature measurements verify cold-ice conditions and indicate ice frozen to bedrock (Fig. 5). The mean air temperature is $-6.9^{\circ} \mathrm{C}$ for the 2-year period 1 November $2017-31$ October 2019 ( $\mathrm{T} \max :+11.1^{\circ} \mathrm{C}$, $\mathrm{T} \mathrm{min}:-33.1^{\circ} \mathrm{C}$ ). Ice flow velocities at the ice divide were measured at stakes with differential GPS. Within the measurement accuracy of $\pm 10 \mathrm{~cm}$, no motion was detected between July 2017 and October 2019.

Ice core drilling and core handling. Two cores were drilled at the same location on WSS down to bed using a 2" electro-mechanical drill ${ }^{36}$. Cores were packed on site into insulating boxes and transported via coldstorage transport to the cold-room facilities $\left(-20^{\circ} \mathrm{C}\right)$ of the Institute of Environmental Physics, Heidelberg University. The visual stratigraphy of the ice cores showed white, bubble-rich ice layers, occasionally interrupted by $\mathrm{cm}$-thick clear layers of refrozen meltwater. The lowermost $30 \mathrm{~cm}$ of the cores showed small rocks incorporated into the ice, a clear sign of bedrock proximity. This is consistent with scratch marks on the cutters of the core barrel after the last drilling run to bedrock. No further ice could be recovered, providing clear evidence that bedrock had been reached. 


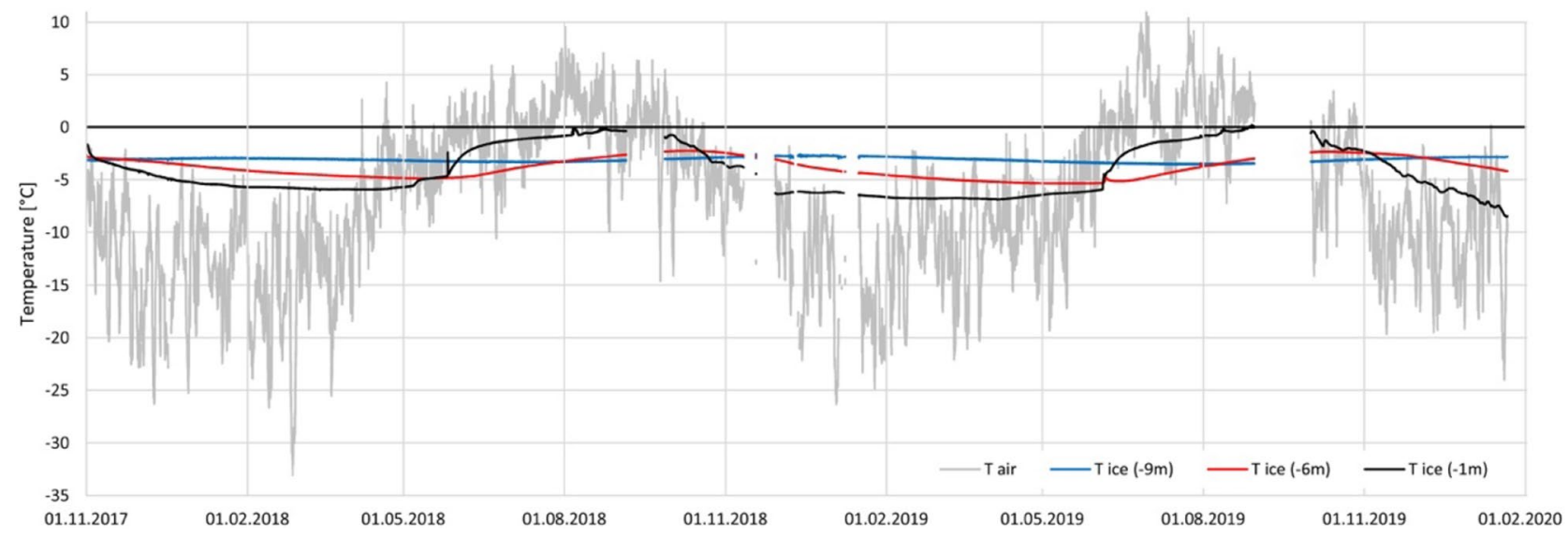

Figure 5. Results from englacial temperatures from the automatic weather station at the WSS summit (grey: air temperature, blue: ice temperature at $9 \mathrm{~m}$ depth, red: ice temperature at $6 \mathrm{~m}$ depth, black: ice temperature at $1 \mathrm{~m}$ depth). Sub-zero temperatures at $9 \mathrm{~m}$ depth with a mean temperature of $-3.1^{\circ} \mathrm{C}$ for the whole period indicate that the basal ice below is frozen to bedrock, despite air temperatures of up to $11.1^{\circ} \mathrm{C}$ inducing strong surface melt. Figure made with licensed software Microsoft Excel 2016 (https://www.microsoft.com/).

\begin{tabular}{|l|c|l|l|l|}
\hline Sample & Depth range $(\mathbf{c m})$ & Measurement $(\mathbf{m B q} / \mathbf{k g})$ & Uncertainty $(\mathbf{m B q} / \mathbf{k g})$ & Detection limit $(\mathbf{m B q} / \mathbf{k g})$ \\
\hline Shallow core 1 top & $0-34$ & 838 & 35 & 47 \\
\hline Shallow core 1 middle & $116-147$ & 484 & 35 & 47 \\
\hline Shallow core 1 bottom & $214-247$ & $<47$ & - & 47 \\
\hline Shallow core 2 top & $0-34$ & 1345 & 35 & 59 \\
\hline Shallow core 2 middle & $213.5-247.5$ & 602 & 35 & 59 \\
\hline Shallow core 2 bottom & $454.5-488.5$ & 118 & 35 & 59 \\
\hline Shallow core 4 top & $0-28$ & 1015 & 35 & 47 \\
\hline Shallow core 4 middle & $82-114$ & 486 & 35 & 47 \\
\hline Shallow core 4 bottom & $118-217.5$ & 57 & 47 & 47 \\
\hline
\end{tabular}

Table 3. Tritium concentrations of three shallow cores drilled at the WSS summit in 2018.

Tritium and stable water isotope analysis. In addition to the deep cores drilled to bedrock, three shallow cores were drilled to $3-4 \mathrm{~m}$ depth, at positions around the location of the deep ice core drilling. From the shallow cores, three samples each of $300 \mathrm{ml}$ (i.e. $34 \mathrm{~cm}$ length) were prepared from the top, bottom and an intermediate section. The samples were shipped with cold-storage transport to Seibersdorf Laboratories, Seibersdorf, Austria, where tritium was measured after electrolytic enrichment, which was necessary because of the low concentrations (Table 3). From the main ice core drilled to bedrock, subsamples for stable water isotope analysis were cut manually at $5 \mathrm{~cm}$ intervals to $8.3 \mathrm{~m}$ depth and at $2.5 \mathrm{~cm}$ between $8.3 \mathrm{~m}$ and the end of the core $(11.13 \mathrm{~m})$. Measurements were performed at the Institute of Environmental Physics, Heidelberg University, using a cavity ring-down spectrometer. Measurement uncertainties range within \pm 0.1 and $\pm 0.4 \%$ for $\delta^{18} \mathrm{O}$ and $\delta \mathrm{D}$, respectively ${ }^{12}$. Calculating ordinary linear regression of $\delta \mathrm{D}$ against $\delta^{18} \mathrm{O}$ yields a slope of 7.5 at a correlation coefficient of $r=0.99$ (Fig. 6). The slope lies close to the global meteoric water line (slope 8), whereas melting and refreezing would lead to reduced values of the slope ${ }^{37}$. Hence, the co-isotopic analysis presents no clear signs of isotopic change after ice formation for the bulk part of the stratigraphy.

Aerosol-based micro-radiocarbon ice dating. A total of six samples selected for micro-radiocarbon dating (55-70 cm in length) was shipped via cold-storage transport to the Paul Scherrer Institute (PSI). There, samples were rinsed with ultrapure water to remove the potentially contaminated outer layer. Around $20-30 \%$ of the ice mass was lost in this step. Samples were melted at room temperature in 1L containers (Semadeni, PETG) and filtered with prebaked $\left(5 \mathrm{~h}\right.$ at $\left.800^{\circ} \mathrm{C}\right)$ quartz-fiber filters. The Water Insoluble Organic Carbon (WIOC) and Elemental Carbon (EC) fractions were separated using a commercial combustion system (Sunset Laboratory Inc., USA) with a recently developed thermal-optical method (Swiss_4S). The resulting $\mathrm{CO}_{2}$ was quantified with a non-dispersive infrared (NDIR) detector at the Laboratory for the Analysis of Radiocarbon with AMS (LARA Laboratory) of the University of Bern. The Sunset instrument is coupled to a gas introduction interface system (GIS), which in turn is coupled to a MIni radioCArbon DAting System (MICADAS; developed at ETH Zurich). The system allows online ${ }^{14} \mathrm{C}$ measurements of the carbonaceous fractions separated by the Sunset. ${ }^{14} \mathrm{C}$ ages were calibrated using OxCal software with the Northern Hemisphere (IntCal13, no significant changes are 


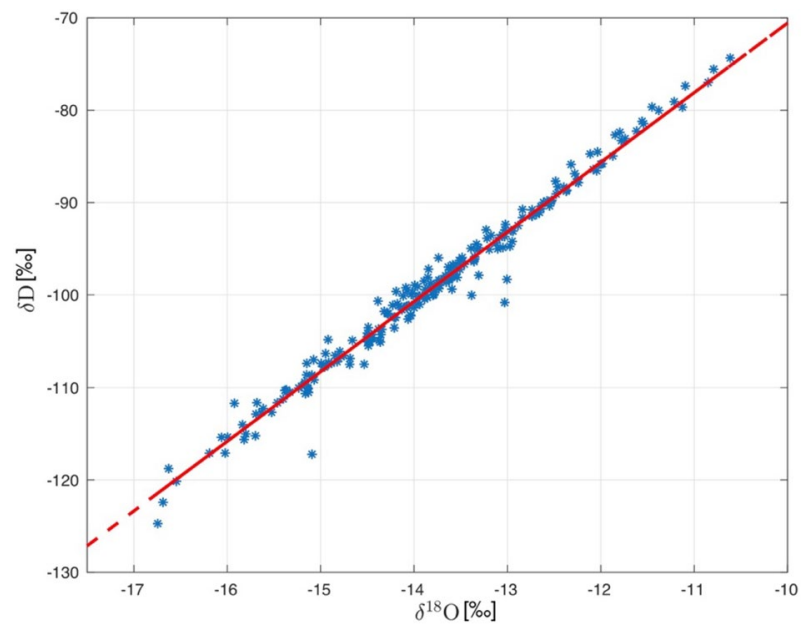

Figure 6. Results from co-isotopic analysis of the WSS ice core. $\delta \mathrm{D}$ and $\delta^{18} \mathrm{O}$ are closely correlated $(\mathrm{r}=0.99)$. Linear regression results in a slope of 7.5, close to the global meteoric water line. Figure made with licensed software MATLAB R2019 (https://www.mathworks.com).

\begin{tabular}{|l|l|l|l|l|l|c|}
\hline Core section & Depth $(\mathbf{m})$ & Ice mass $(\mathrm{g})$ & WIOC $(\boldsymbol{\mu g})$ & Be no & $\mathbf{F}^{14} \mathbf{C}$ & ${ }^{14} \mathbf{C}$ age $($ Cal-BP) \\
\hline WS7 & 5.46 & 397.7 & 170.4 & $12,317.1 .1$ & $0.930 \pm 0.046$ & $623 \pm 350$ \\
\hline WS9 & 6.47 & 251.9 & 19.8 & $12,741.1 .1$ & $0.910 \pm 0.019$ & $735 \pm 145$ \\
\hline WS12 & 8.33 & 434.5 & 87.8 & $12,318.1 .1$ & $0.847 \pm 0.046$ & $1347 \pm 456$ \\
\hline WS16 & 10.57 & 296.1 & 68.9 & $12,742.1 .1$ & $0.657 \pm 0.013$ & $3661 \pm 200$ \\
\hline WS17-1 & 11.13 & 174.9 & 7.2 & $11,922.1 .1$ & $0.529 \pm 0.041$ & $5884 \pm 739$ \\
\hline WS17-2 & Basal ice & 151.6 & 104.9 & $11,921.1 .1$ & $0.223 \pm 0.006$ & $14,020 \pm 332$ \\
\hline
\end{tabular}

Table 4. Micro-radiocarbon dating results. ${ }^{a}$ Due to visible silt material and high organic carbon content, the nominal age of the lowermost basal sample is biased by reservoir effects. It is reported for completeness but was not considered further for interpretation.

observed when using IntCal20) calibration curve $\mathrm{e}^{38,39}$. The micro-radiocarbon dating results are summarized in the Table 4.

Received: 9 June 2020; Accepted: 11 November 2020

Published online: 17 December 2020

\section{References}

1. Zekollari, H., Huss, M. \& Farinotti, D. Modelling the future evolution of glaciers in the European Alps under the EURO-CORDEX RCM ensemble. Cryosphere 13, 1125-1146 (2019).

2. Haeberli, W., Oerlemans, J., \& Zemp, M. The future of alpine glaciers and beyond. In Oxford Research Encyclopedia of Climate Science (ed. von Storch, H.) (Oxford University Press, Oxford, 2019).

3. Solomina, O. N. et al. Holocene glacier fluctuations. Quat. Sci. Rev. 111, 9-34 (2015).

4. Moran, A. P., Ivy Ochs, S., Christl, M. \& Kerschner, H. Exposure dating of a pronounced glacier advance at the onset of the lateHolocene in the central Tyrolean Alps. Holocene 27, 1350-1358 (2017).

5. Hormes, A., Müller, B. U. \& Schlüchter, C. The Alps with little ice: evidence for eight Holocene phases of reduced glacier extent in the Central Swiss Alps. Holocene 11, 255-265 (2001).

6. Joerin, U. E., Stocker, T. F. \& Schlüchter, C. Multicentury glacier fluctuations in the Swiss Alps during the Holocene. Holocene 16, 697-704 (2006).

7. Grosjean, M., Suter, P. J., Trachsel, M. \& Wanner, H. Ice-borne prehistoric finds in the Swiss Alps reflect Holocene glacier fluctuations. J. Quat. Sci. 22, 203-207 (2007).

8. Bohleber, P. Alpine ice cores as climate and environmental archives. In Oxford Research Encyclopedia of Climate Science (ed. von Storch, H.) (Oxford University Press, Oxford, 2019).

9. Gabrielli, P. et al. Age of the Mt. Ortles ice cores, the Tyrolean Iceman and glaciation of the highest summit of South Tyrol since the Northern Hemisphere Climatic Optimum. Cryosphere 10, 2779-2797 (2016).

10. Pavlova, P. A. et al. Polychlorinated biphenyls in a temperate alpine glacier: 1 . Effect of percolating meltwater on their distribution in glacier ice. Environ. Sci Technol. 49, 14085-14091 (2015).

11. Cuffey, K. \& Patterson, W. S. B. The Physics of Glaciers (Academic Press, London, 2010).

12. Bohleber, P., Hoffmann, H., Kerch, J., Sold, L. \& Fischer, A. Investigating cold based summit glaciers through direct access to the glacier base: a case study constraining the maximum age of Chli Titlis glacier, Switzerland. Cryosphere 12, 401-412 (2018).

13. Haeberli, W., Frauenfelder, R., Kääb, A. \& Wagner, S. Characteristics and potential climatic significance of "miniature ice caps" (crest-and cornice-type low-altitude ice archives). J. Glaciol. 50, 129-136 (2004).

14. Baroni, C. \& Orombelli, G. The alpine "Iceman" and Holocene climatic change. Quat. Res. 46, 78-83 (1996). 
15. Hafner, A. Archaeological discoveries on Schnidejoch and at other ice sites in the European Alps. Arctic 65, 189-202 (2012).

16. Kutschera, W. \& Müller, W. "Isotope language" of the Alpine Iceman investigated with AMS and MS. Nucl. Instrum. Methods Phys. Res. Sect. B Beam Interact. Mater. Atoms 204, 705-719 (2003).

17. Holzhauser, H., Magny, M. \& Zumbuühl, H. J. Glacier and lake-level variations in west-central Europe over the last 3500 years. Holocene 15, 789-801 (2005).

18. Bortenschlager, S., Kofler, W., Oeggl, K., Schoch, W. Erste Ergebnisse der Auswertung der vegetabilischen Reste vom Hauslabjochfund. in Der Mann im Eis, 307-312 (Universität Innsbruck, Innsbruck, 1992).

19. Jenk, T. M. et al. A novel radiocarbon dating technique applied to an ice core from the Alps indicating late Pleistocene ages. J. Geophys. Res. Atmos. 114, D14305 (2009).

20. Hoffmann, H. et al. A new sample preparation system for Micro-14 C dating of glacier ice with a first application to a high Alpine ice core from Colle Gnifetti (Switzerland). Radiocarbon 60, 517-533 (2018).

21. Nicolussi, K. \& Patzelt, G. Untersuchungen zur holozänen Gletscherentwicklung von Pasterze und Gepatschferner (Ostalpen). Z. Gletscherkunde und Glazialgeologie 36, 1-88 (2000).

22. Ivy-Ochs, S. et al. Latest Pleistocene and Holocene glacier variations in the European Alps. Quat. Sci. Rev. 28, 2137-2149 (2009).

23. Kalis, A. J., Merkt, J. \& Wunderlich, J. Environmental changes during the Holocene climatic optimum in central Europe-human impact and natural causes. Quat. Sci. Rev. 22, 33-79 (2003).

24. Vollweiler, N., Scholz, D., Mühlinghaus, C., Mangini, A., \& Spötl, C. A precisely dated climate record for the last 9 kyr from three high alpine stalagmites, Spannagel Cave, Austria. Geophys. Res. Lett. 33, L20703 (2006).

25. Nicolussi, K., Matuschik, I., Tegel, W. Klimavariabilität und Siedlungsdynamik am Beispiel der Feuchtbodensiedlungen im Raum Oberschwaben, Bodensee und Nordostschweiz 4400-3400 BC. Dendro Chronologie, -Typologie, Ökologie. Festschrift für André Billamboz zum 65. Geburtstag 1, 69-85 (2013).

26. Nicolussi, K., Kaufmann, M., Patzelt, G. \& Thurner, A. Holocene tree-line variability in the Kauner Valley, Central Eastern Alps, indicated by dendrochronological analysis of living trees and subfossil logs. Veg. Hist. Archaeobot. 14, 221-234 (2005).

27. Ilyashuk, E. A., Koinig, K. A., Heiri, O., Ilyashuk, B. P. \& Psenner, R. Holocene temperature variations at a high-altitude site in the Eastern Alps: a chironomid record from Schwarzsee ob Sölden, Austria. Quat. Sci. Rev. 30, 176-191 (2011).

28. Patzelt, G. Das Bunte Moor in der Oberfernau (Stubaier Alpen, Tirol)_Eine neu bearbeitete Schlüsselstelle für die Kenntnis der nacheiszeitlichen. Gletscherschwankungen der Ostalpen-Jahrbuch der Geologischen Bundesanstalt 156, 97-107 (2016).

29. Abermann, J., Kuhn, M. \& Fischer, A. Climatic controls of glacier distribution and glacier changes in Austria. Ann. Glaciol 52, 83-90 (2011).

30. Vincent, C. et al. Strong changes in englacial temperatures despite insignificant changes in ice thickness at Dôme du Goûter glacier (Mont Blanc area). Cryosphere 14, 925-934 (2020).

31. May, B. L. Radiocarbon Microanalysis on Ice Impurities for Dating of Alpine glaciers. Ph.D. thesis (Heidelberg University, 2009).

32. Preunkert, S. et al. Lead and antimony in basal ice from Col du Dome (French Alps) dated with radiocarbon: a record of pollution during antiquity. Geophys. Res. Lett. 46, 4953-4961 (2019).

33. Hou, S. et al. Age ranges of the Tibetan ice cores with emphasis on the Chongce ice cores, western Kunlun Mountains. Cryosphere 12, 2341-2348 (2018).

34. Zemp, M. Glacier monitoring tracks progress in limiting climate change. Nature 576, 39-39 (2019).

35. Vincent, C. et al. Common climatic signal from glaciers in the European Alps over the last 50 years. Geophys. Res. Lett. 44, 1376-1383 (2017).

36. Ginot, P. et al. FELICS, a new ice core drilling system for high-altitude glaciers. Mem. Natl Inst. Polar Res Spec. Issue 56, 38-48 (2002).

37. Souchez, R. A. \& Jouzel, J. On the isotopic composition in $\delta \mathrm{D}$ and $\delta 18 \mathrm{O}$ of water and ice during freezing. J. Glaciol. 30, 369-372 (1984).

38. Ramsey, C. B. \& Lee, S. Recent and planned developments of the program OxCal. Radiocarbon 55, 720-730 (2013).

39. Reimer, P. J. et al. IntCal13 and Marine13 radiocarbon age calibration curves $0-50,000$ years cal BP. Radiocarbon 55, 1869-1887 (2013).

\section{Acknowledgements}

The authors would like to thank the members of the field work teams at Weißseespitze. We gratefully acknowledge Kati Heinrich's assistance in figure production, Brigitte Scott's language editing and Josef Lier's help with ice core handling. Part of this work was performed within the Cold Ice project funded by the Austrian Science Fund (FWF): P 29256-N36. Partial financial support was provided to PB from the European Union's Horizon 2020 research and innovation programme under the Marie Skłodowska-Curie Grant Agreement No. 790280. The authors thank Melaine Le Roy and Bethan Davies for their helpful comments on the manuscript.

\section{Author contributions}

P.B., M.S.W. and A.F. contributed with the WSS ice core reconnaissance and drilling. For the WSS ice core, radiocarbon sample preparation, analysis and interpretation were performed by M.S. and L.F. Collection of other data were conducted by P.B. and A.F. M.S.W. measured ice flow velocities, ice temperatures and mass balance at WSS. P.B. wrote an initial version of the manuscript. All authors contributed to the final version of the manuscript.

\section{Competing interests}

The authors declare no competing interests.

\section{Additional information}

Correspondence and requests for materials should be addressed to P.B.

Reprints and permissions information is available at www.nature.com/reprints.

Publisher's note Springer Nature remains neutral with regard to jurisdictional claims in published maps and institutional affiliations. 
(c) (i) Open Access This article is licensed under a Creative Commons Attribution 4.0 International cc) License, which permits use, sharing, adaptation, distribution and reproduction in any medium or format, as long as you give appropriate credit to the original author(s) and the source, provide a link to the Creative Commons licence, and indicate if changes were made. The images or other third party material in this article are included in the article's Creative Commons licence, unless indicated otherwise in a credit line to the material. If material is not included in the article's Creative Commons licence and your intended use is not permitted by statutory regulation or exceeds the permitted use, you will need to obtain permission directly from the copyright holder. To view a copy of this licence, visit http://creativecommons.org/licenses/by/4.0/.

(C) The Author(s) 2020 